\title{
The effects of drought and fire in the extirpation of an abundant semi-aquatic turtle from a lacustrine environment in the southwestern USA
}

\author{
Jeffrey Edward Lovich ${ }^{1, *}$, Mari Quillman ${ }^{2}$, Brian Zitt ${ }^{2}$, Adam Schroeder ${ }^{2}$, David Earl Green ${ }^{3}$, \\ Charles Yackulic ${ }^{1}$, Paul Gibbons ${ }^{4}$ and Eric Goode ${ }^{4}$ \\ ${ }^{1}$ U.S. Geological Survey, Southwest Biological Science Center, 2255 North Gemini Drive, MS-9394, Flagstaff, AZ 86001-1600, USA \\ 2 ECORP Consulting, Inc., 1801 Park Court Place, B-103, Santa Ana, CA 92701, USA \\ ${ }^{3}$ U.S. Geological Survey, National Wildlife Health Center, 6006 Schroeder Road, Madison, WI 53711-6223, USA \\ 4 Turtle Conservancy, 49 Bleecker Street, Suite 601, New York, NY 10012, USA
}

\begin{abstract}
We documented a significant mortality event affecting a southwestern pond turtle (Actinemys pallida) population living in a lake in southern California, USA. The area around the lake was impacted by a large wildland fire in 2013 that occurred during a protracted drought. As the mortality event was still unfolding, we collected data in 2014 on water quality, demographic structure, and short-term survivorship of the population. Water quality was poor with low levels of dissolved oxygen and high salinity of up to $45.90 \mathrm{ppt}$. Many turtles were severely emaciated and coated with a pale mineralized layer on their shells and skin. Estimated survival rate was low leading to a projected $90 \%$ decline in 134 days and a high probability of extirpation within a year. The lake was dry in September 2015 with no evidence of live turtles. Necropsies and low volumetric body condition indices suggested death by starvation. Although this semi-aquatic species has the ability to aestivate in upland habitats during periods of low water or move to other nearby water bodies, it is unlikely that many were able to do so because of their extremely poor condition and the severity of the drought conditions throughout the area.
\end{abstract}

Keywords: climate / evaporite / starvation / survivorship / water quality

Résumé - Les effets de la sécheresse et du feu dans l'anéantissement d'un abondant vertébré semiaquatique dans un milieu lacustre du sud-ouest des États-Unis. Nous avons relevé un événement de forte mortalité affectant une population de tortues du sud-ouest (Actinemys pallida) vivant dans un lac au sud de la Californie, États-Unis. Les environs du lac ont été touchés par un grand incendie forestier en 2013 qui s'était produit au cours d'une sécheresse prolongée. Comme l'événement de mortalité continuait à se dérouler, nous avions recueilli des données en 2014 sur la qualité de l'eau et sur la structure démographique et la survie à court terme de la population. La qualité de l'eau était faible avec de bas niveaux d'oxygène dissous et une salinité élevée allant jusqu'à 45,90 ppm. De nombreuses tortues étaient gravement émaciées et revêtues d'une couche minéralisée pâle sur leurs carapaces et leurs peaux. Le taux de survie estimé était faible, ce qui a entraîné un déclin attendu de $90 \%$ en 134 jours et une probabilité de disparition élevée dans un délai d'un an. Le lac était à sec en septembre 2015 sans aucune preuve de tortues vivantes. Des nécropsies et de faibles indices de condition corporelle volumétrique suggéraient la mort par inanition. Bien que cette espèce semi-aquatique ait la capacité d'estiver dans les habitats des hautes-terres pendant les périodes de basses eaux ou de se déplacer vers d'autres plans d'eau avoisinants, il est peu probable que beaucoup de tortues aient pu le faire en raison de leur très mauvais état et de la sévérité des conditions de sécheresse dans toute la région.

Mots clés : climat / évaporite / inanition / survie / qualité de l'eau

\footnotetext{
* Corresponding author: jeffrey_lovich@usgs.gov
} 


\section{Introduction}

Fire and drought are naturally occurring disturbances that have profound impacts on ecosystems and ecological processes, either singly or in synergy. Climate change, particularly due to warming, is expected to increase the recurrence and duration of extreme weather events like prolonged drought with greater impacts on ecosystem function than associated shifts in average climatic conditions alone (Jentsch and Beierkuhnlein, 2008). The change in drought frequency and duration is predicted to be especially strong in the southwestern United States (Cook et al., 2004; Archer and Predick, 2008; Woodhouse et al., 2010), exceeding even the driest conditions seen during the Medieval Climate Anomaly (Cook et al., 2015). In turn, droughts and other factors (e.g., spread of non-native grasses) contribute to large-wildfire frequency, longer wildfire durations and wildfire seasons (Westerling et al., 2006; Archer and Predick, 2008) and increased wildlife mortality (Bury, 2004; Lovich et al., 2014) in the western United States.

Aquatic ecosystems are particularly at risk of the effects of drought and fire, even if the documented impacts are largely scattered in the scientific literature, fragmentary, and based on opportunistic research (Lake, 2003). In addition, available research is often of relatively short duration and based on small spatial scales (Humphries and Baldwin, 2003; Matthews and Marsh-Matthews, 2003). Nevertheless, drought affects stream ecosystems both directly and indirectly (Lake, 2003). Direct effects include loss of water, loss of habitat for aquatic species, and loss of stream connectivity. Indirect effects include reduced water quality, alteration of food resources, and changes in interspecific interactions. Collectively, these effects alter population demography, community structure and diversity, and ecosystem processes (Lake, 2003). As noted recently, we know even less about the ecological effects of water level fluctuations in lentic ecosystems (Wantzen et al., 2008). The effects of fire on lotic and lentic ecosystems are largely related to inputs from smoke, ash and erosional material from the affected drainage basin that alter water chemistry (Korhola et al., 1996; Earl and Blinn, 2003; Ranalli, 2004; Verkaik et al., 2013a). Conversely, under certain circumstances, fire can play a critical role in maintaining aquatic ecological diversity in some ecosystems (Bisson et al., 2003).

As a group, semi-aquatic turtles are model organisms to study the effects of both drought and fire. Like many amphibian species, their "dual citizenship" in terrestrial and aquatic habitats makes them susceptible to a broad array of impacts that cross the boundary between wetlands and terra firma (e.g., Bennett et al., 1970; Burke and Gibbons, 1995; Buhlmann and Gibbons, 2001; Zaragoza et al., 2015). In addition, many turtle species can achieve high population densities (Congdon et al., 1986), they are relatively easy to capture (Gibbons, 1988), and their bony shell can bear evidence of fire if they survive (Mitchell et al., 2005; Lovich et al., 2011a) or it remains as evidence of mortality if they do not (Esque et al., 2003; Lovich et al., 2011b).

Not surprisingly, most research on the effects of drought on turtles is focused on aquatic species. Research demonstrates that drought affects aquatic and semi-aquatic turtle activity and behavior (Christiansen and Bickham, 1989;
Anthonysamy et al., 2013; Rowe et al., 2013), stress hormones (Cash and Holberton, 2005), reproduction and emigration (Gibbons et al., 1983), and population size and survival (Lindeman and Rabe, 1990; Rees et al., 2009; Olivier et al., 2010; Leidy et al., 2016). Publications on the effects of fire on turtles are confined almost exclusively to those documenting mortality in tortoises (Stubbs et al., 1985; Hailey, 2000; Esque et al., 2002; Lovich et al., 2011a) and other terrestrial species (Ernst et al., 1995; Platt et al., 2010; Howey and Roosenburg, 2013).

Beginning in the summer of 2014, we studied an ongoing mass mortality event of a southwestern pond turtle (Actinemys pallida) population living in a lake in southern California, USA. This species is considered to be a species of special concern by the California Department of Fish and Wildlife (Thomson et al., 2016). The area around the lake was severely affected by a large wildland fire in 2013 that occurred during a protracted drought that was then in the second year (Mann and Gleick, 2015). The ongoing drought contributed to the size and severity of the fire. In turn, ash inputs during and after the fire contributed to the deterioration in water quality already caused by the drought. As the mortality event was unfolding, we collected data in year three of the drought on the demographic structure and survivorship of the population that we compared to published data for populations of this species and the closely related A. marmorata living under more favorable conditions. In addition, we conducted necropsies to determine the mechanisms of mortality in the population. To the best of our knowledge, this is the first study to examine the interaction of fire and drought on the survival, behavior and pathology of a semi-aquatic turtle population.

\section{Materials and methods}

\subsection{Study site description}

When full, Elizabeth Lake is a long $(\approx 2.7 \times 0.3 \mathrm{~km}) \mathrm{sag}$ pond located on Castaic Creek (a tributary of the Santa Clara River) along the San Andreas Fault in northern Los Angeles County, California about $27 \mathrm{~km}$ northwest of Palmdale, California (Figs. 1 and 2). It is situated near western Antelope Valley in the foothills of the Sierra Pelona Mountains at an elevation of about $1000 \mathrm{~m}$. Small tributaries and storm drains provide seasonal runoff that feed Elizabeth Lake during rainfall events. The region is characterized by a Mediterranean climate with hot dry summers and cool wet winters (Gasith and Resh, 1999). The shoreline has remained mostly undeveloped, with the exception of a day use area on U.S. Forest Service property on the northern border and low-density housing on the privately held east end of the lake. Although formerly popular with anglers when full of water, there was no evidence of fish in the lake when we began our studies.

The area surrounding the lake was affected by the "Powerhouse Fire" (http://inciweb.nwcg.gov/incident/3399/, accessed 20 February, 2017) that started on 30 May 2013 and burned through heavy fuels consisting of dense brush (chaparral) that transitions to lighter desert scrub. The fire burned until 10 June 2013 affecting over $122.5 \mathrm{~km}^{2}$ that completely encompassed the area around Elizabeth Lake (Staley et al., 2013). Water was removed from the lake by firefighting 


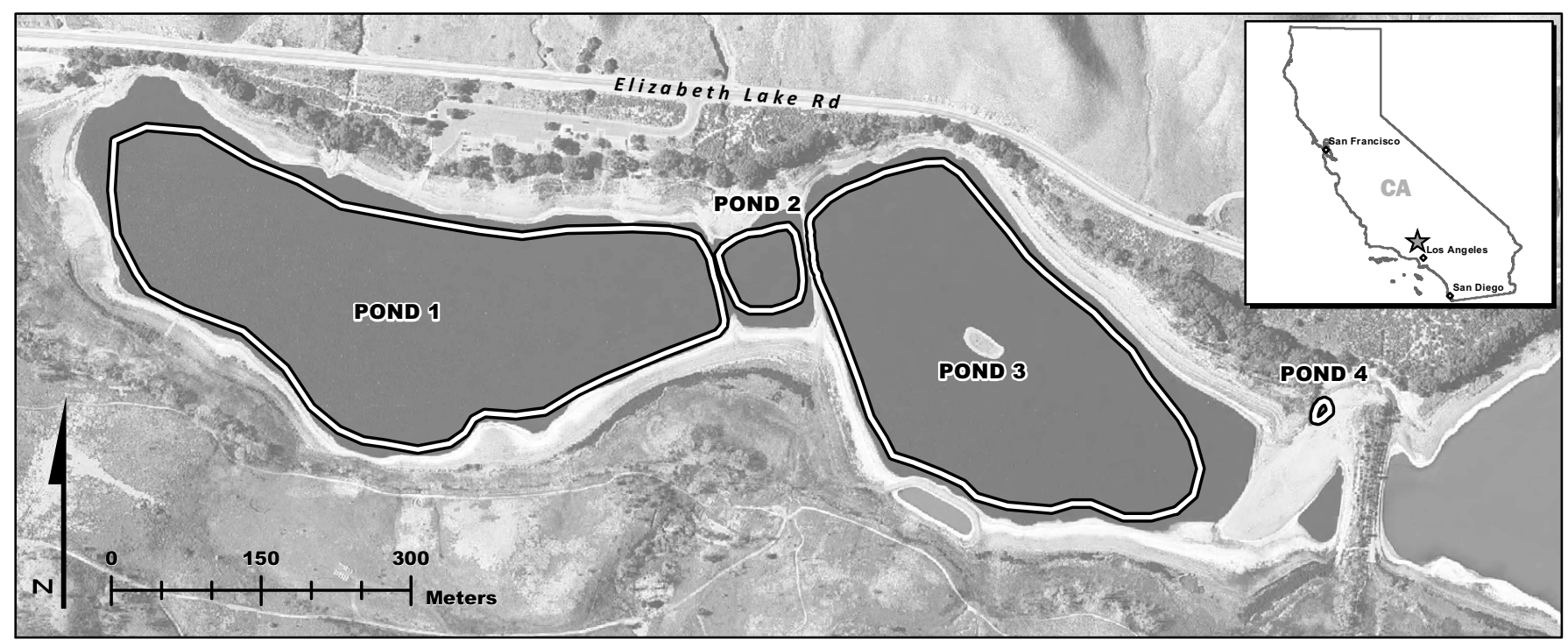

Fig. 1. Map of Elizabeth Lake in Los Angeles County, California, USA. Aerial image from 14 May 2014. Lines inside shoreline approximate the water level when measured with GPS on 28 August 2014.

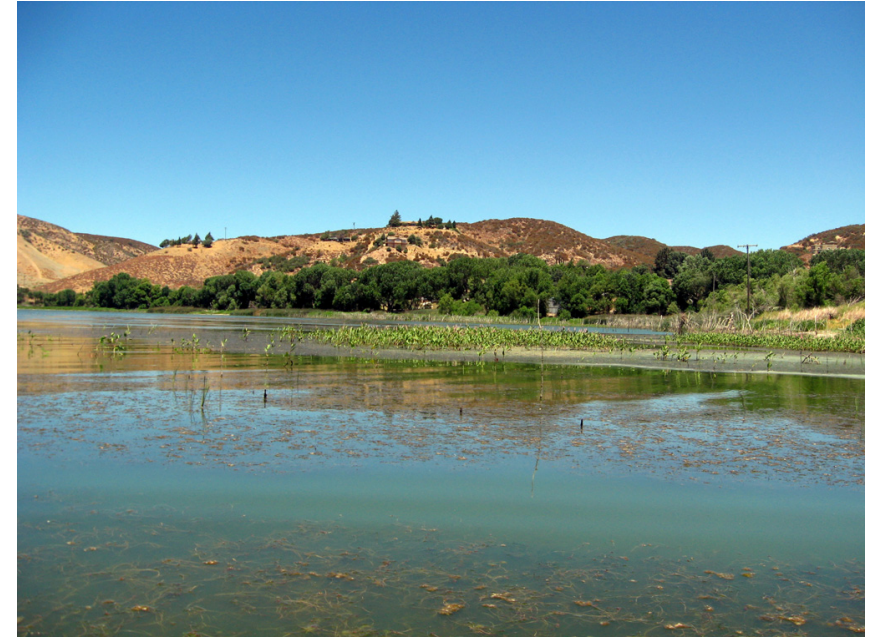

Fig. 2. Photograph of Elizabeth Lake, Los Angeles County, California, USA taken on 22 July 2008 by Mari Quillman.

helicopters (see https://www.youtube.com/watch?v=0HXKE_D2Os, accessed 20 February, 2017 and other videos) and this likely exacerbated the decrease in water level due to the drought alone. The fire occurred during the second year of an ongoing and severe drought, extending into a fourth year (Diffenbaugh et al., 2015; Mann and Gleick, 2015) as our sampling ended in September 2015. After the fire, massive inputs of ash were observed in the lake by some of the authors but water quality samples were not collected at that time. According to the United States Drought Monitor for California (http://droughtmonitor. unl.edu/Home/StateDroughtMonitor.aspx?CA, accessed 18 December, 2015), the area was categorized as being in Extreme Drought or Exceptional Drought between 18 March 2014 and 17 March 2015 (Fig. 3). Conditions between 2012 and 2014 constitute the worst drought for central and southern California in the last 1200 years (Griffin and Anchukaitis, 2014) based on paleoclimate reconstructions.

\subsection{Sampling techniques}

We collected $A$. pallida during two time periods: 25-29 August and 16-18 September, 2014. Previously recognized as A. marmorata pallida, and sometimes referred to the genus Emys, the taxonomy of this species has been in flux (Ernst and Lovich, 2009; Spinks et al., 2014, 2016). However, the turtles in Elizabeth Lake are assigned to A. (or Emys) pallida (Thomson et al., 2016). During our surveys, the water remaining in Elizabeth Lake formed four separate ponds with the three larger ones isolated by narrow earthen dykes that would normally be submerged when the lake was full. Ponds 1, 2 , and the western portion of pond 3 are administered by the U.S. Forest Service for recreation as part of the Angeles National Forest, while pond 4 and the eastern portion of pond 3 are not. In addition, the lake was revisited by one of the authors (JEL) on 16 September 2015 and the perimeter of the now dried ponds was surveyed for evidence of live turtles and carcasses. At that time the lake was dry except for a few very small wet areas that were devoid of turtles or other aquatic vertebrates. It is likely that the wet areas were completely dry prior to the area receiving $1.3 \mathrm{~cm}$ of rain on 15 September 2015, as recorded at nearby Palmdale, California, USA, approximately $27 \mathrm{~km}$ distant.

We captured the majority of turtles by hand $(>60 \%$ of all captures) but we also used dip nets, a seine, a fyke net and baited turtle traps (Gibbons, 1988). Traps were baited with cans of sardines in oil or cat food, both of which are effective in attracting turtles into traps. Traps were checked daily and bait was replaced every other day. Some, but not all, of the trap locations were changed between sample periods. This was done to add variation to the sampling and concentrate efforts where higher densities of pond turtles were observed.

\subsection{Data collection and analysis}

Water quality and weather conditions were recorded daily during the turtle trapping surveys. Water quality data were 


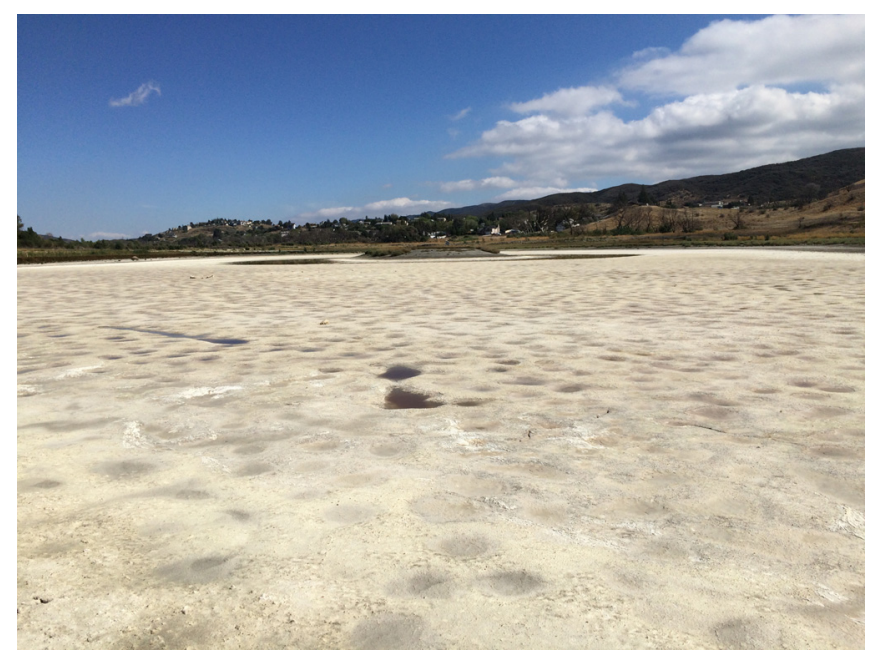

Fig. 3. Photograph of Elizabeth Lake, Los Angeles County, California, USA taken on 16 September 2015 by Jeffrey Lovich, in the fourth year of drought and 2 years after the Powerhouse Fire. Note salt encrustation of surface and small accumulations of water remaining in the foreground and background.

collected in four locations (identified as ponds 1 through 4 ) on various dates during and after both sampling periods (August 25-29, September 16-18, and November 24, 2014). A multiparameter water quality meter (HORIBA Model U-52) was used to record water temperature, conductivity, salinity, dissolved oxygen, total dissolved solids, $\mathrm{pH}$, turbidity, and oxidationreduction potential. The water quality meter was calibrated according to the manufacturer's instructions prior to each survey.

Mineralized layers observed on the shell and extremities of turtles (described in Sect. 3) were scraped off a single dead turtle and sent to Babcock Laboratories, Inc. (Riverside, California, USA) for chemical analysis using standard methods (e.g., EPA 6010B, EPA 300.0, EPA 9060, EPA 6020 , and $\mathrm{SM} 4500 \mathrm{NO}_{2} \mathrm{~B}$ ) for analyte detection including anions, cations, organic compounds, and nutrients.

Turtles were photographed, sexed, measured, weighed, marked, and examined for any observable health issues (e.g., parasites, lesions, damage to shell or limbs). Sex was determined by observing the location of the vent in relation to the carapace margin. Measurements consisted of straightline mid-carapace length (CL), straight-line mid-plastron length, carapace width $(\mathrm{CW})$ and carapace height $(\mathrm{CH})$, the latter two taken between the 2 nd and 3 rd vertebral scutes. We also measured body mass with Pesola ${ }^{\circledR}$ spring scales to the nearest gram. We used $\log _{10}$ transformed CL to compare mean body size of males and females with a $t$-test (using SYSTAT Version 13 software) since those data conformed to the assumption of normality. The sex ratio of males and females was compared with a chi-squared $\left(\chi^{2}\right)$ test.

Following Ashton et al. (2015), we calculated volumetric body condition indices (vBCI) of male and female turtles using the formula:

$$
\mathrm{vBCI}=\text { body mass } /(\pi \times \mathrm{CL} \times \mathrm{CW} \times \mathrm{CH} / 6) .
$$

This allowed us to approximate the body density (Loehr et al., 2007) and compare our values against data presented by
Ashton et al. for turtles that were not subjected to severe drought and fire. Turtles were permanently marked by notching unique combinations of marginal scutes with a triangular file. The left femoral scute of the plastron was also notched as a cohort mark. Once processed, all turtles were placed into freshwater holding bins prior to their release back into the lake. Non-native turtles captured (11 Trachemys scripta) during the course of these surveys were donated to the Orange County Turtle and Tortoise Club.Freshly dead turtles were collected opportunistically, put on wet ice (usually the day they died), and packed for expedited shipping to the U.S. Geological Survey, National Wildlife Health Center in Madison, Wisconsin, USA. Five A. pallida and one T. scripta were necropsied by an experienced wildlife disease veterinary pathologist. Necropsies included histological preparations as well as cultures for viruses, bacteria, and Mycoplasma that will be described in more detail in a separate publication.

Mark-recapture data were fit using Burnham's version of the Jolly-Seber model (Burnham, 1991) in program MARK. This model estimates initial abundance, lambda (i.e., proportional change in abundance between two time periods including both survival and recruitment), survival and detection probabilities. Given the short period of the study we assumed no recruitment to the adult population over the course of the study when live turtles were collected. As a result, we set lambda equal to survival. Survival was calculated for all turtles captured (males, females and immatures) on a per day basis and assumed constant over the 24-day study period. Given variation in sampling effort and gear we estimated different capture probabilities for each day of sampling. Although we could have reached similar estimates of detection probability and survival using a Cormack-Jolly-Seber model, the main advantage of our approach was that initial abundance was estimated as part of the likelihood, as opposed to as a derived parameter. Future projections of population abundance were based on the maximum likelihood estimates of the initial abundance and the daily survival, as well as their associated covariances, and assumed that there was no future recruitment to the population. Survival of a salvaged, random sample of 32 turtles that were taken from the lake and placed under veterinary care at the Turtle Conservancy (www.turtleconserv ancy.org) in nearby Ojai, California in September 2014 was also monitored.

\section{Results}

\subsection{Water quality}

The physical and chemical characteristics of water in Elizabeth Lake varied based on time of sampling and location within and among ponds (Tab. 1). Overall, readings indicated high salinity (to $45.90 \mathrm{ppt}$ ) across ponds with mean values of $20.48 \mathrm{ppt}$ (pond 1), 25.48 ppt (pond 2), and 21.98 ppt (pond 3). Pond 4 was the least saline $(\bar{x}=8.18 \mathrm{ppt})$, possibly due to spring discharges. High salinities were reflected in high conductivity measurements (to $68.40 \mathrm{mS} / \mathrm{cm}$ ). There were high loads of total dissolved solids (to $41.00 \mathrm{~g} / \mathrm{L}$ ) and the water was extremely turbid at $>1000$ Nephelometric Turbidity Units. Water temperatures ranged from 9.80 to $28.64{ }^{\circ} \mathrm{C}$ and alkaline conditions prevailed with $\mathrm{pH}$ ranging from 8.36 to 9.69. Other water quality parameters are summarized in Table 1. 
Table 1. Water quality parameters for ponded remnants of Elizabeth Lake, Los Angeles County, California, USA during a protracted drought. Values marked with an asterisk were instrument maxima or would not stabilize and are not included in calculated means for each pond. In particular, dissolved oxygen values marked with an asterisk are errors based on solubility data presented by Carpenter (1966).

\begin{tabular}{|c|c|c|c|c|c|c|c|c|c|c|}
\hline Location & Date & $\begin{array}{l}\text { Time } \\
(24 \mathrm{~h})\end{array}$ & $\begin{array}{l}\text { Temperature } \\
\left({ }^{\circ} \mathrm{C}\right)\end{array}$ & $\mathrm{pH}$ & $\begin{array}{l}\text { Conductivity } \\
(\mathrm{mS} / \mathrm{cm})\end{array}$ & $\begin{array}{l}\text { Salinity } \\
\text { (ppt) }\end{array}$ & $\begin{array}{l}\text { Dissolved } \\
\text { oxygen }(\mathrm{mg} / \mathrm{L})\end{array}$ & $\begin{array}{l}\text { Turbidity } \\
\text { (NTU) }\end{array}$ & $\begin{array}{l}\text { Total dissolved } \\
\text { solids }(\mathrm{g} / \mathrm{L})\end{array}$ & $\begin{array}{l}\text { Oxidation-reduction } \\
\text { potential (ORPmV) }\end{array}$ \\
\hline \multirow[t]{5}{*}{ Pond 1} & $8 / 28 / 2014$ & $11: 27$ & 24.11 & 9.13 & 18.10 & 10.7 & $23.14^{*}$ & 304.0 & 11.30 & 52 \\
\hline & $9 / 16 / 2014$ & $11: 37$ & 26.55 & 8.66 & 33.60 & 21.0 & 12.03 & 459.0 & 20.50 & 72 \\
\hline & $9 / 17 / 2014$ & $13: 53$ & 28.64 & 9.09 & 34.00 & 21.3 & 8.50 & 153.0 & 20.70 & 59 \\
\hline & $11 / 24 / 2014$ & $12: 49$ & 10.19 & 8.4 & 45.80 & 28.9 & $16.44^{*}$ & $>1000^{*}$ & 27.90 & -116 \\
\hline & & $\bar{x}$ & 22.37 & 8.82 & 32.88 & 20.48 & 10.27 & 305.33 & 20.10 & 16.75 \\
\hline \multirow[t]{6}{*}{ Pond 2} & $8 / 25 / 2014$ & $07: 50$ & 16.25 & 8.73 & 20.80 & 12.4 & 2.94 & 780.0 & 12.90 & -113 \\
\hline & $8 / 28 / 2014$ & $11: 29$ & 20.94 & 8.95 & 21.70 & 13.0 & 3.58 & 573.0 & 13.40 & -19 \\
\hline & $9 / 16 / 2014$ & $11: 40$ & 19.71 & 8.7 & 43.50 & 27.9 & 1.80 & 670.0 & 26.50 & -231 \\
\hline & $9 / 17 / 2014$ & $13: 57$ & 25.41 & 8.91 & 43.80 & 28.2 & $22.75^{*}$ & 885.0 & 26.70 & 83 \\
\hline & $11 / 24 / 2014$ & $12: 53$ & 14.18 & 8.36 & 68.40 & 45.9 & 1.25 & $>1000^{*}$ & 41.00 & -220 \\
\hline & & $\bar{x}$ & 19.30 & 8.73 & 39.64 & 25.48 & 2.39 & 727.00 & 24.10 & -100.00 \\
\hline \multirow[t]{5}{*}{ Pond 3} & $8 / 28 / 2014$ & $11: 33$ & 21.39 & 8.95 & 18.90 & 11.2 & 1.59 & 257.0 & 11.70 & -144 \\
\hline & $9 / 16 / 2014$ & $11: 45$ & 21.14 & 9 & 33.40 & 20.9 & 5.74 & 154.0 & 20.40 & 21 \\
\hline & $9 / 17 / 2014$ & $14: 08$ & 23.16 & 8.95 & 33.80 & 21.2 & 1.27 & 746.0 & 20.60 & -39 \\
\hline & $11 / 24 / 2014$ & $13: 16$ & 9.80 & 8.7 & 53.90 & 34.6 & 3.00 & $>1000^{*}$ & 32.30 & -3 \\
\hline & & $\bar{x}$ & 18.87 & 8.90 & 35.00 & 21.98 & 2.90 & 385.67 & 21.25 & -41.25 \\
\hline \multirow[t]{5}{*}{ Pond 4} & $8 / 29 / 2014$ & $06: 57$ & 18.37 & 9.68 & 8.82 & 5.0 & 2.24 & $>1000^{*}$ & 5.55 & -255 \\
\hline & $9 / 17 / 2014$ & $11: 33$ & 19.09 & 9.69 & 13.20 & 7.6 & 7.45 & $>1000^{*}$ & 8.20 & -81 \\
\hline & $9 / 18 / 2014$ & $06: 25$ & 17.95 & 9.53 & 11.50 & 6.6 & 2.69 & $>1000^{*}$ & 7.12 & -304 \\
\hline & $11 / 24 / 2014$ & $13: 37$ & 11.00 & 9.21 & 22.90 & 13.5 & $23.21^{*}$ & $>1000^{*}$ & 14.20 & 59 \\
\hline & & $\bar{x}$ & 16.60 & 9.53 & 14.11 & 8.18 & 4.13 & $>1000$ & 8.77 & -145.25 \\
\hline
\end{tabular}

\subsection{Demography and survival}

First captures included 126 turtles with 51 females, 41 males, and 34 immature or unsexed $A$. pallida. The relative proportions of males and females did not differ significantly from $1: 1\left(\chi^{2}=1.09, \mathrm{df}=1\right.$, two-tailed $\left.P=0.30\right)$. Of the 222 captures and recaptures of $A$. pallida, 126 individuals were captured only once, 52 twice, 26 three times, 12 four times, 5 five times, and one individual was captured six times. The population was comprised of a wide range of body sizes from immatures to adults (Fig. 4). Mean CL of individual females was $15.5 \mathrm{~cm}$ (standard deviation $(\mathrm{SD})=1.0$, range $12.9-17.6 \mathrm{~cm})$. Mean $\mathrm{CL}$ of males was $15.9 \mathrm{~cm}(\mathrm{SD}=1.5$, range $12.7-19.4 \mathrm{~cm})$. Mean CL of immatures was $10.5 \mathrm{~cm}$ $(\mathrm{SD}=1.5$, range $7.8-12.7 \mathrm{~cm})$. The mean $\mathrm{CL}$ of males was not significantly greater than females (one-tailed $t$-test with separate variances, $t=-1.32, \mathrm{df}=67.61, P=0.90)$. Only 11 live $T$. scripta were caught (six females, one male and four immature specimens) during our sampling with a mean CL of $16.9 \mathrm{~cm}(\mathrm{SD}=3.8$, range $11.7-22.2 \mathrm{~cm})$.

The initial population was estimated at $170 \quad(95 \%$ confidence interval (CI) 150-201) and the daily survival rate was estimated at $0.983(95 \%$ CI $0.969-0.997)$. At the end of 24 days, the population was estimated to have been 114 (95\% CI 86-150). If maintained these survival rates would lead to a $90 \%$ decline in 134 days (95\% CI 73-766 days) and a high probability of extirpation or near extirpation over the course of a year (Fig. 5). The only other aquatic vertebrates observed at the time of sampling in 2014 were African clawed frogs (Xenopus laevis), a species with toxic skin secretions that protects it from predation by other reptiles (Barthalmus and Zielinski, 1988; Zielinski and Barthalmus, 1989).

In September of 2015, the lake was almost completely dry. An estimated less than 0.5 ha of shallow water remained in three small isolated pools. The pools were shallow (less than $0.3 \mathrm{~m}$ ) with a reddish tint to the translucent water and devoid of any visible life. Fish bones were observed on the lake bed. The remains of five A. pallida were found (Fig. 6), including two marked by us a year earlier. Mean CL of the dead turtles (two males, two females, one immature) that had complete skeletal remains was $13.8 \mathrm{~cm}(\mathrm{SD}=2.07$, range $11.3-15.7 \mathrm{~cm})$.

Salvaged live turtles taken to the Turtle Conservancy and placed under veterinary care and nearly ideal captive conditions in 2014 continued to present with various health problems. These included lethargy, skin lesions, serosanguinous fluid from scute junctions on the carapace, sunken eyes, marked gas accumulation in the region of the stomach and intestines and inability to submerge, slow response to stimuli, pneumonia, and distended bladders. Most of the turtles continued to lose weight for the duration of their captivity. This was observed 


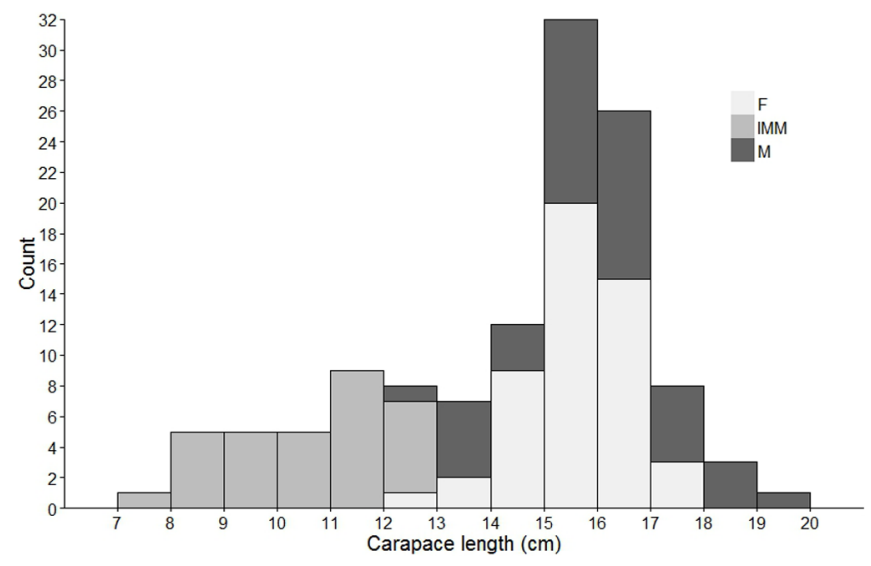

Fig. 4. Histogram of straight-line carapace length distribution of southwestern pond turtles $(n=122)$ in Elizabeth Lake, Los Angeles County, California. Sex-indeterminate specimens were excluded from our sample. Sexes are shaded as $\mathrm{F}=$ female, $\mathrm{M}=$ male, and IMM = immature.

despite the fact that all turtles were observed to eat in the summer, fall and spring. Six of 32 turtles $(18.8 \%)$ died before the remainder were released at a pond west of Elizabeth Lake on 12 May 2015 by the California Department of Fish and Wildlife. The status of the released turtles is unknown.

\subsection{Turtle physical condition}

Many of the turtles were covered with a light gray coating of evaporites (Fig. 6) previously unreported in the literature for this or other turtle species to the best of our knowledge and experience. It required considerable effort to remove the coatings even after they softened somewhat when turtles were placed in fresh water. The coatings varied from paper thin to $2.7 \mathrm{~mm}$ in thickness and constituted $10-28 \%$ of the wet mass of five turtles (two males and three immatures, CL range $7.8-17.0 \mathrm{~cm}$ ) after the coating was removed and turtles were reweighed. The coating removed from smaller turtles $(<8.5 \mathrm{~cm}$ CL) averaged $19.2 \%$ of their weight, while the coating removed from larger turtles $(>16.4 \mathrm{~cm}$ CL) averaged only $10.1 \%$ of their weight.

Most of the coating was on the carapace, forelimbs and head, even occluding the nostrils in a few cases. The surface of the coating ranged from smooth to rough and gave the appearance that the turtles were dipped in either plaster of Paris or wet cement (Fig. 6). Mineral composition of the coatings included the cations calcium $(21,000 \mathrm{mg} / \mathrm{kg})$, magnesium $(79,000 \mathrm{mg} / \mathrm{kg})$, sodium $63,000 \mathrm{mg} / \mathrm{kg})$, and potassium $(3700 \mathrm{mg} / \mathrm{kg}) ;$ and the anions chloride $(66,000 \mathrm{mg} / \mathrm{kg})$ and sulfate $(40,000 \mathrm{mg} / \mathrm{kg})$. Nutrients such as nitrates and nitrites were not detected. Total phosphorus content was $760 \mathrm{mg} / \mathrm{kg}$.

Values of vBCI for females had a mean of 0.98 (standard error $=0.01$ ) while males had a mean of 1.04 (standard error $=0.02$ ). Two turtles had swallowed fish hooks (see Steen et al., 2014) and monofilament line was protruding from their mouths. Many turtles also appeared to be emaciated and weak upon capture. When placed in bins of freshwater for holding while processing, many of the turtles drank copiously.

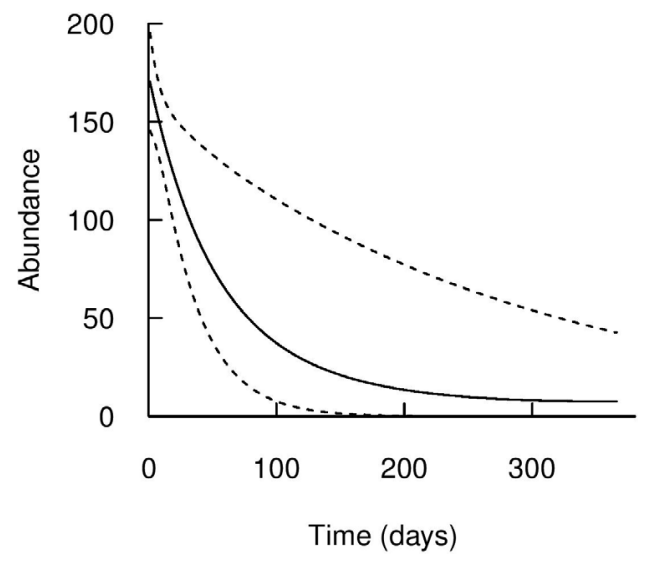

Fig. 5. Estimated abundance of southwestern pond turtles (Actinemys pallida) in Elizabeth Lake, Los Angeles County, California, USA based on daily survivorship estimates from August to September, 2015. Dashed lines represent 95\% CI boundaries.

\subsection{Necropsy findings}

All turtles examined were severely emaciated with atrophy of skeletal muscles and all body fat, and empty or partially blood-filled gastro-intestinal tracts. Moderate to severe anemia was suspected in four turtles based on absence of blood in the heart and pallor of the viscera. Anemia may have been due to a combination of emaciation, malnutrition, and bleeding into the gastro-intestinal tract, the latter common in many animals suffering from severe starvation. The lungs of two turtles showed signs of mild to severe bacterial pneumonia that could have contributed to the anemia or just as likely occurred after the turtles began starving. Ranavirus did not contribute to the deaths of necropsied turtles and no viruses were isolated from esophagi, spleens, livers or kidneys. Bacterial cultures identified 2-5 genera in the nasal washes, lungs and livers of each turtle. Minimal numbers of parasitic protozoan and helminthic parasites were found in Actinemys and Trachemys.

\section{Discussion}

\subsection{Drought and fire effects on turtle populations and ecosystem consequences}

Along with the increased frequency and duration of droughts in the southwest USA, California experienced the worst drought in recorded history (Griffin and Anchukaitis, 2014; Diffenbaugh et al., 2015; Mann and Gleick, 2015), that entered the fourth year of below average precipitation and above average temperatures in 2015 . The duration and severity of the drought have already had effects on wildlife populations and plant community structure in the southwestern USA as described and reviewed recently by Lovich et al. (2014). More specifically, drought has previously been implicated in declines of Actinemys populations in California (Leidy et al., 2016) with some populations experiencing reductions of $85 \%$ or more (Holland, 1994). Adding increased risk of fires to the already significant effects of drought complicates efforts to protect wetlands.

Our results underscore the negative impact of drought and fire on an ecologically important organism. Under natural 


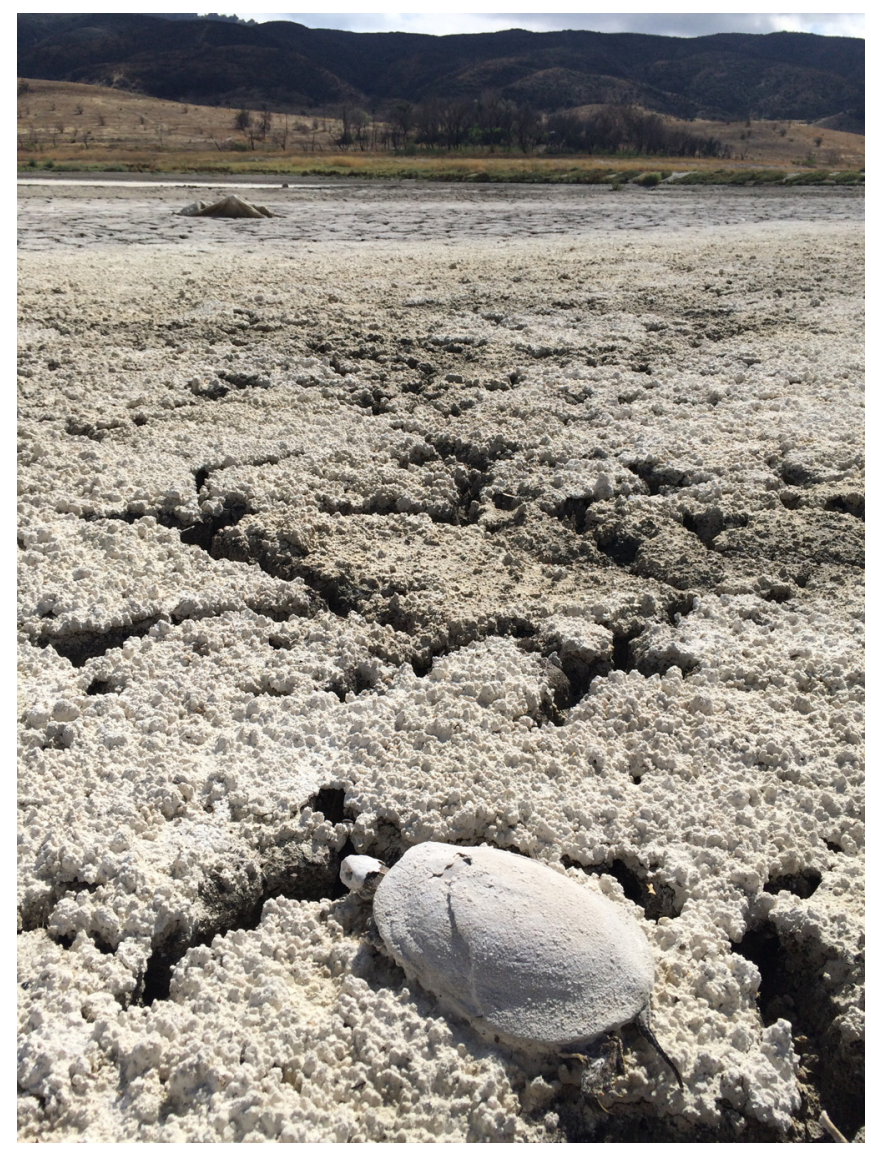

Fig. 6. Salt-encrusted remains of a southwestern pond turtle (Actinemys pallida) as found in the dry lake bed of Elizabeth Lake, Los Angeles County, California, USA on September 16 2015. Note the heavy coating of evaporites on the carcass. Most living turtles collected in 2014 had similar but varying degrees of coatings on the head, limbs and shell. Photo by Jeff Lovich.

conditions, turtles, by virtue of their long lives, overlapping generations, and low energetic demands make substantial contributions to the biomass of the ecosystems they occupy. Turtle biomasses are some of the highest reported for vertebrates and are typically an order of magnitude higher than those for warm-blooded animals (Iverson, 1982; Congdon et al., 1986). Due to their numerical dominance in the standing crop biomass of many communities, turtles occupy important ecological and trophic positions related to nutrient and mineral cycling (Ernst and Lovich, 2009). The loss of turtle populations can thus have important consequences on ecosystem structure and function (Hunter et al., 2013; Froyd et al., 2014; Hunter and Gibbs, 2014). Unfortunately, no previous studies are available to document the size of the turtle population before the drought and fire at Elizabeth Lake but unpublished observations suggest they were very conspicuous and abundant.

\subsection{Collapse of the food base during drought and starvation of turtles}

The high rates of turtle mortality we observed, coupled with the drying of the lake, strongly suggest that the turtle population was extirpated within a year of the start of our sampling. The size structure we observed (Fig. 3) was typical of the species under natural conditions (Bury et al., 2012) and did not suggest that mortality affected the sexes or size classes differentially. Necropsy findings of emaciation, empty gastro-intestinal tracts, and depletion of fat stores suggest that the mechanism of decline was due to starvation with severe depletion of fat stores. Starvation was attributed to local depletion of food sources, loss of aquatic habitat (very low water levels), rising salinity and crowding. The high salinity may have also contributed to starvation since small individuals of some freshwater species do not maintain mass or grow in $41-59 \%$ sea water even when fed ad libitum (Dunson and Seidel, 1986). In fact, freshwater and estuarine turtles exposed to high salinities respond by not feeding or drinking (Davenport and Wong, 1986). The absence of fish in the lake when we sampled in 2014 (and presence of fish bones in the dry lake bed in 2015) is evidence of a large change in the food web that ultimately affected turtles. Although A. pallida is an opportunistic omnivore that infrequently eats fish, we observed little if anything in the lake during our sampling that is known to be included in their diet (Ernst and Lovich, 2009; Bury et al., 2012).

Drought is known to have significant impacts on lentic ecology and food webs. Included are reductions in littoral zone productivity with possible negative effects higher up the trophic system as well as eutrophication (Wantzen et al., 2008). In addition, direct and indirect effects of water level fluctuations in lakes include reduced population densities (including turtles: Lindeman and Rabe, 1990), species richness and community structure, altered life-history traits, strength of biotic interactions, changes in predation and competition, and changes in food resources and ecosystem processes (Lake, 2003). Concentration of large numbers of dying turtles in drying water bodies during drought has been documented from the Jurassic Period (Wings et al., 2012) to modern times (Christiansen and Bickham, 1989; Chessman, 2011). According to local informants, this is not the first time that Elizabeth Lake became dry but the mass mortality we observed happened during the worst drought in California history coincident with a large wildfire.

\subsection{Fire effects on water quality}

The role of fire in the decline of water quality and food web integrity at Elizabeth Lake was likely due to large inputs of ash, sediment and nutrients during and following the fire (see review in Ranalli, 2004). Water quality parameters that change following a fire include increased pH (Korhola et al., 1996), increased nutrients (Verkaik et al., 2013a) including ammonium, nitrate, soluble reactive phosphorus (but see Stephens et al., 2004), increased turbidity and conductivity, decreased dissolved oxygen (Earl and Blinn, 2003), increased suspended sediment exports (Smith et al., 2011), and a minimal to dramatic negative influence (Verkaik et al., 2013a) on macroinvertebrate density (an important food source for A. pallida: Ernst and Lovich, 2009; Bury et al., 2012) that can last for 1-4 years in stream environments (Earl and Blinn, 2003; Verkaik et al., 2013a). The magnitude and duration of impacts varies widely (Ranalli, 2004) but can be long-lasting (e.g., pH, Korsman and Segerstrom, 1998). 
Drought can prolong the effects of fire in Mediterranean climate ecosystems (Verkaik et al., 2013a) and may even have a stronger influence on macroinvertebrate community structure than fire (Verkaik et al., 2013b).

\subsection{Turtles and poor water quality}

Some turtles are able to live in polluted environments (Graham and Perkins, 1976; Moll, 1980; Sidis and Gasith, 1985; Swartz et al., 2003; Matson et al., 2005), including sewage ponds (Germano, 2010) occupied by Actinemys. Turtles of the genus Actinemys can tolerate such conditions as long as they have food, contaminants are not highly toxic (e.g., Luke and Sterner, 2000) and their immune systems are not overly compromised (Polo-Cavia et al., 2010). Our water quality data reflect changes associated with drought and fire that appear to have been severe enough to result in a collapse of the food web in Elizabeth Lake through deterioration of water quantity and quality, ultimately leading to starvation of turtles exacerbated by a reduced feeding response from increased salinity. Starvation, and potentially high osmotic stress (Dunson and Seidel, 1986) is also indicated by dehydrated turtles drinking (Peterson and Greenshields, 2001) when taken out of the saline lake and placed in bins of freshwater.

\subsection{Reduced body condition of turtles and poor water quality}

Water availability and temperature have strong effects on the ecology and behavior of A. marmorata. Populations inhabiting intermittent streams exhibit lower body conditions than those in perennial streams (Bondi and Marks, 2013). Ashton et al. (2015) studied populations occupying two very different forks of the Trinity River in California providing vBCI values for comparison and contrast with our sample. The Main Fork of the Trinity River has a dam that results in altered flows and colder summer discharge temperatures than the unregulated and normothermic South Fork. In their study, vBCI for females was significantly higher on the Main Fork than the South Fork. They attributed the difference to the possibility that turtles in the former had to store additional resources as a physiological response to the colder water temperatures.

Our mean values for both males and females were lower than those Ashton et al. estimated for turtles in the Main Fork of the Trinity River. Our female vBCI mean was lower than those from the South Fork while male means were comparable between the studies. Ashton et al. attributed the differences to water temperature differences between the forks that have adverse effects on growth (see also Snover et al., 2015), resource assimilation and body condition in the Main (cold fork). Overall, our values suggest that vBCI values of Elizabeth Lake turtles were lower than expected for Actinemys under more optimal conditions described by Ashton et al. The low vBCI values of Elizabeth Lake turtles compared to other studies provides additional support for starvation and dehydration through osmotic stress. It is important to note that the vBCI calculations for Elizabeth Lake included the sometimes heavy coating of evaporites on turtles' shells (Fig. 6). As a result, our vBCI values are inflated, some substantially so, and turtles at Elizabeth Lake were in poorer condition than the results would indicate. Mineral analysis of the coatings is consistent with mobilization of ash inputs of cations into the lake following the fire (Ranalli, 2004) and reflected in our water quality data (Tab. 1).

\subsection{Alternative hypotheses for the disappearance of turtles as the lake evaporated}

Since A. pallida is a semi-aquatic species, an alternative hypothesis to the one we present is that the turtles simply moved away from the lake as it was drying to find other water sources or to enter dormancy on dry land awaiting wetter conditions or better water quality. As discussed in recent papers on terrestrial habitat use by Actinemys (Pilliod et al., 2013; Zaragoza et al., 2015), these turtles often spend considerable time in terrestrial habitats, including in southern California. Terrestrial occupation can encompass half of a year or more out of water sometimes hundreds of meters into upland habitats. However, populations in streams are more likely to leave the water during the winter to overwinter in terrestrial habitats (e.g., Rathbun et al., 2002) than populations in more permanent ponds (Lovich and Meyer, 2002; Bondi and Marks, 2013). Use of terrestrial habitat may span the winter during overwintering but can occur at other times of the year as well.

It is unlikely that turtles could have survived terrestrial habitat occupancy due to the effects of the fire on surrounding vegetation and leaf litter, their poor body condition/health, and the severity of the ongoing drought. Their poor body condition was likely exacerbated by the heavy coatings of evaporites on their shells. Evaporite deposition was a likely consequence of increasing concentrations of minerals as the lake dried, augmented by additional mineral inputs of ash from the fire, and not a result of parasites (e.g., Bower et al., 2012) or other factors. In addition, the light color of the evaporites, compared to the normal dark brown ground color of shells, may have limited their ability to achieve operative body temperatures while basking (Schwarzkopf and Brooks, 1985) further compromising their condition. The ability to attain operative body temperature affects metabolism, digestion, reproduction, and growth (Ernst and Lovich, 2009). Even when placed under veterinary care, a subsample of turtles from Elizabeth Lake continued to present with health issues and a high mortality rate, an indicator of their poor condition.

It is also possible that some turtles were able to emigrate to small ponds on surrounding private land that are supplemented by underground pumping. Examination of aerial photos during the drought revealed only two small ponds in the vicinity and it is unlikely that they could support a large number of turtles emigrating away from Elizabeth Lake across a landscape fragmented by roads and low-density housing. Others have demonstrated that turtles will use suburban water bodies during droughts that affect more ephemeral natural wetlands (Roe et al., 2011). However we were unable to sample ponds near Elizabeth Lake.

\section{Conclusion}

Drought and fire can act together to drastically alter populations, communities, and ecosystems in ways that may 
not be obvious from consideration of drought and fire in isolation. Based on the available evidence, our working hypothesis for the possible extirpation of this population is as follows. The synergistic interaction between fire and protracted drought caused a rapid deterioration in water quality (in part, manifested by evaporite coatings on turtles) and quantity ultimately causing the collapse of the food web. Reductions in water quantity were likely exacerbated by water removal from the lake by firefighting aircraft during the Powerhouse Fire. Ironically, Holland (1994) reported two cases of $A$. marmorata being dropped from helicopter water tanks during similar firefighting operations in Oregon and California. Evidence from our necropsies support the conclusion that the deaths we observed came as a result of what may have been months of starvation. This appears to have eliminated all living turtles that remained in the lake by 2015 , or within 1 year, as our survivorship estimate in 2014 suggested. It is possible that the population would have been able to survive the effects of drought or fire alone, but the combination appears to be responsible for the extirpation observed. Given the likelihood of increasing drought frequency in California's future (Diffenbaugh et al., 2015), conservation of $A$. pallida as a species of special concern, along with other sensitive aquatic organisms, will become an even greater challenge.

Acknowledgments. Special thanks to Dr. Hon Ip and Renee Long who assisted with virus cultures, Brenda Berlowsky who assisted with bacterial and mycoplasmal cultures and identifications, and Mauritz Sterner who identified helminths. Stephanie Steinfeldt assisted in tissue preparations for histological examination. Hayley Mandaro provided field assistance. An earlier version of the manuscript benefited greatly from comments offered by $\mathrm{R}$. Bruce Bury, Ted Kennedy, and Shellie Puffer. Mohammed Znari kindly provided the French translation of our abstract. Research was supported by a grant from the Desert Tortoise Council. All research was permitted by the California Department of Fish and Wildlife and the U.S. Forest Service. Animal handling protocols were approved by the Institutional Animal Care and Use Committee of Northern Arizona University. Any use of trade, firm, or product names is for descriptive purposes only and does not imply endorsement by the U.S. Government.

\section{References}

Anthonysamy WJB, Dreslik MJ, Phillips CA. 2013. Disruptive influences of drought on the activity of a freshwater turtle. Am Midl Nat 169: 322-335.

Archer SR, Predick KI. 2008. Climate change and ecosystems of the Southwestern United States. Rangelands 30: 23-28.

Ashton DT, Bettaso JB, Welsh HH Jr. 2015. Changes across a decade in size, growth, and body condition of western pond turtle (Actinemys marmorata) populations on free-flowing and regulated forks of the Trinity River in northwest California. Copeia 103: 621-633.

Barthalmus GT, Zielinski WJ. 1988. Xenopus skin mucus induces oral dyskinesias that promote escape from snakes. Pharmacol Biochem Behav 30: 957-959.
Bennett DH, Gibbons JW, Franson JC. 1970. Terrestrial activity in aquatic turtles. Ecology 51: 738-740.

Bisson PA, Rieman BE, Luce C, et al. 2003. Fire and aquatic ecosystems of the western USA: current knowledge and key questions. For Ecol Manage 178: 213-229.

Bondi CA, Marks SB. 2013. Differences in flow regime influence the seasonal migrations, body size, and body condition of western pond turtles (Actinemys marmorata) that inhabit perennial and intermittent riverine sites in northern California. Copeia 2013: 142-153.

Bower DS, Death CE, Georges A. 2012. Ecological and physiological impacts of salinisation on freshwater turtles of the lower Murray River. Wildl Res 39: 705-710.

Buhlmann KA, Gibbons JW. 2001. Terrestrial habitat use by aquatic turtles from a seasonally fluctuating wetland: implications for wetland conservation boudaries. Chelonian Conserv Biol 4: 115-127.

Burke VJ, Gibbons JW. 1995. Terrerstrial buffer zones and wetland conservation: a case study of freshwater turtles in a Carolina bay. Conserv Biol 9: 1365-1369.

Burnham KP. 1991. On a unified theory for release-resampling of animal populations. In: Chao MT, Cheng PE, eds. Proceedings of 1990 Taipei Symposium in Statistics. Taipei, Taiwan: Institute of Statistical Science, Academia Sinica. pp. 11-36.

Bury RB. 2004. Wildfire, fuel reduction, and herpetofaunas across diverse landscape mosaics in northwestern forests. Conserv Biol 18: 968-975.

Bury RB, Ashton DT, Welsh HH Jr. 2012. Synopsis of biology. In: Bury RB, Welsh HH Jr, Germano DJ, Ashton DT, eds. Western pond turtle - biology, sampling techniques, inventory and monitoring, conservation and management: northwest fauna. Olympia: The Society for Northwestern Vertebrate Biology, pp. 9-19.

Carpenter JH. 1966. New measurements of oxygen soluability in pure and natural water. Limnol Oceanogr 11: 264-277.

Cash WB, Holberton RL. 2005. Endocrine and behavioral response to a decline in habitat quality: effects of pond drying on the slider turtle, Trachemys scripta. J Exp Zool A Comp Exp Biol 303: 872-879.

Chessman BC. 2011. Declines of freshwater turtles associated with climatic drying in Australia's Murray-Darling Basin. Wildl Res 38: 664-671.

Christiansen JL, Bickham JW. 1989. Possible historic effects of pond drying and winter kill on the behavior of Kinosternon flavescens and Chrysemys picta. J Herpetol 23: 91-94.

Congdon JD, Greene JL, Gibbons JW. 1986. Biomass of freshwater turtles: a geographic comparison. Am Midl Nat 115: 165-173.

Cook BI, Ault TR, Smerdon JE. 2015. Unprecedented 21st century drought risk in the American Southwest and Central Plains. Sci Adv 1: e1400082.

Cook ER, Woodhouse CA, Eakin CM, Meko DM, Stahle DW. 2004. Long-term aridity changes in the western United States. Science 306: $1015-1018$.

Davenport J, Wong TM. 1986. Observations on the water economy of the estuarine turtles Batagur baska (Gray) and Callagur borneoensis (Schlegel and Muller). Comp Biochem Physiol 84A: 703-707.

Diffenbaugh NS, Swain DL, Touma D. 2015. Anthropogenic warming has increased drought risk in California. Proc Natl Acad Sci USA 112: 3931-3936.

Dunson WA, Seidel ME. 1986. Salinity tolerance of estuarine and insular emydid turtles (Pseudemys nelsoni and Trachemys decussata). J Herpetol 20: 237-245.

Earl SR, Blinn DW. 2003. Effects of wildfire ash on water chemistry and biota in southwestern U.S.A. streams. Freshw Biol 48: $1015-1030$.

Ernst CH, Lovich JE. 2009. Turtles of the United States and Canada, 2nd ed. Baltimore: Johns Hopkins University Press, 827 p. 
Ernst CH, Boucher TP, Sekscienski SW, Wilgenbusch JC. 1995. Fire ecology of the Florida box turtle, Terrapene carolina bauri. Herpetol Rev 26: 185-187.

Esque TC, Búrquez-Montijo A, Schwalbe CR, Van Devender TR, Anning PJ, Nijhuis MJ. 2002. Fire ecology of the Sonoran desert tortoise. In: Van Devender TR, ed. The Sonoran desert tortoise: natural history, biology, and conservation. Tucson: University of Arizona Press and The Arizona-Sonora Desert Museum, pp. 312-333.

Esque TC, Schwalbe CR, Defalco LA, Duncan RB, Hughes TJ. 2003. Effects of desert wildfires on desert tortoises (Gopherus agassizii) and other small vertebrates. Southwest Nat 48: 103-111.

Froyd CA, Coffey EED, Van Der Knaap WO, Van Leeuwen JFN, Tye A, Willis KJ. 2014. The ecological consequences of megafaunal loss: giant tortoises and wetland biodiversity. Ecol Lett 17: 144-154.

Gasith A, Resh VH. 1999. Streams in Mediterranean climate regions: abiotic influences and biotic responses to predictable seasonal events. Annu Rev Ecol Syst 30: 51-81.

Germano DJ. 2010. Ecology of western pond turtles (Actinemys marmorata) at sewage-treatment facilities in the San Joaquin Valley, California. Southwest Nat 55: 89-97.

Gibbons JW. 1988. Turtle population studies. Carolina Tips 51: 4547.

Gibbons JW, Greene JL, Congdon JD. 1983. Drought-related responses of aquatic turtle populations. J Herpetol 17: 242-246.

Graham TE, Perkins RW. 1976. Growth of the common snapping turtle, Chelydra s. serpentina in a polluted marsh. Bull Md Herpetol Soc 12: 123-125.

Griffin D, Anchukaitis KJ. 2014. How unusual is the 2012-2014 California drought? Geophys Res Lett 41: 9017-9023.

Hailey A. 2000. The effects of fire and mechanical habitat destruction on survival of the tortoise Testudo hermanni in northern Greece. Biol Conserv 92: 321-333.

Holland DC. 1994. The western pond turtle: habitat and history. Portland, Oregon: Oregon Department of Fish and Wildlife, Final Report to U.S. Department of Energy, 303 p.

Howey CAF, Roosenburg WM. 2013. Effects of prescribed fire on the eastern box turtle (Terrapene carolina carolina). Northeast Nat 20 : 493-497.

Humphries P, Baldwin DS. 2003. Drought and aquatic ecosystems: an introduction. Freshw Biol 48: 1141-1146.

Hunter EA, Gibbs JP. 2014. Densities of ecological replacement herbivores required to restore plant communities: a case study of giant tortoises on Pinta Island, Galápagos. Restor Ecol 22: $248-256$

Hunter EA, Gibbs JP, Cayot LJ, Tapia W. 2013. Equivalency of Galápagos giant tortoises used as ecological replacement species to restore ecosystem functions. Conserv Biol 27: 701-709.

Iverson JB. 1982. Biomass in turtle populations: a neglected subject. Oecologia 55: 69-76.

Jentsch A, Beierkuhnlein C. 2008. Research frontiers in climate change: effects of extreme meteorological events on ecosystems. C R Geosci 340: 621-628.

Korhola A, Virkanen J, Tikkanen M, Blom T. 1996. Fire-induced pH rise in a naturally acid hill-top lake, southern Finland: a palaeoecological survey. $J$ Ecol 84: 257-265.

Korsman T, Segerstrom U. 1998. Forest fire and lake-water acidity in a northern Swedish boreal area: holocene changes in lake-water quality at Makkassjon. $J$ Ecol 86: 113-124.

Lake PS. 2003. Ecological effects of perturbation by drought in flowing waters. Freshw Biol 48: 1161-1172.
Leidy RA, Bogan MT, Neuhaus L, Rosetti L, Carlson SM. 2016. Summer die-off of western pond turtle (Actinemys marmorata) along an intermittent coast range stream in central California. Southwest Nat 61: 71-74.

Lindeman PV, Rabe FW. 1990. Effect of drought on the western painted turtle, Chrysemys picta belli, in a small wetland ecosystem. $J$ Freshwat Ecol 5: 359-364.

Loehr VJT, Hofmeyr MD, Henen BT. 2007. Annual variation in the body condition of a small arid-zone tortoise, Homopus signatus signatus. J Arid Environ 71: 337-349.

Lovich J, Meyer K. 2002. The western pond turtle (Clemmys marmorata) in the Mojave River, California, USA: highly adapted survivor or tenuous relict? J Zool 256: 537-545.

Lovich JE, Ennen JR, Madrak SV, et al. 2011a. Long-term postfire effects on spatial ecology and reproductive output of female Agassiz's desert tortoises (Gopherus agassizii) at a wind energy facility near Palm Springs, California, USA. Fire Ecol 7: $75-87$.

Lovich JE, Ennen JR, Madrak SV, et al. 2011b. Effects of wind energy production on growth, demography, and survivorship of a desert tortoise (Gopherus agassizii) population in southern California with comparisons to natural populations. Herpetol Conserv Biol 6: 161-174.

Lovich JE, Yackulic CB, Freilich J, et al. 2014. Climatic variation and tortoise survival: has a desert species met its match? Biol Conserv 169: 214-224.

Luke C, Sterner D. 2000. Possible impacts of the Cantara spill on reptile populations along the upper Sacramento River. Calif Fish Game 86: 61-71.

Mann ME, Gleick PH. 2015. Climate change and California drought in the 21st century. Proc Natl Acad Sci USA 112: 3858-3859.

Matson CW, Palatnikov G, Islamzadeh A, et al. 2005. Chromosomal damage in two species of aquatic turtles (Emys orbicularis and Mauremys caspica) inhabiting contaminated sites in Azerbaijan. Ecotoxicology 2005: 513-525.

Matthews WJ, Marsh-Matthews E. 2003. Effects of drought on fish across axes of space, time and ecological complexity. Freshw Biol 48: $1232-1253$.

Mitchell JC, Tuberville TD, Buhlmann KA. 2005. Siebenrockiella crassicollis (Black Marsh Turtle). Fire scars. Herpetol Rev 36: 169.

Moll DL. 1980. Dirty river turtles. Nat Hist 89: 42-49.

Olivier A, Barbraud C, Rosecchi E, Germain C, Cheylan M. 2010. Assessing spatial and temporal population dynamics of cryptic species: an example with the European pond turtle. Ecol Appl 20: 993-1004.

Peterson CC, Greenshields D. 2001. Negative test for cloacal drinking in a semi-aquatic turtle (Trachemys scripta), with comments on the functions of cloacal bursae. J Exp Zool 290: 247-254.

Pilliod DS, Welty JL, Stafford R. 2013. Terrestrial movement patterns of western pond turtles (Actinemys marmorata) in central California. Herpetol Conserv Biol 8: 207-221.

Platt SG, Liu H, Borg CK. 2010. Fire ecology of the Florida box turtle (Terrapene carolina bauri Taylor) in pine rockland forests of the lower Florida Keys. Nat Areas $J$ 30: 254-260.

Polo-Cavia N, Engstrom T, López P, Martín J. 2010. Body condition does not predict immunocompetence of western pond turtles in altered versus natural habitats. Anim Conserv 13: 256-264.

Ranalli AJ. 2004. A summary of the scientific literature on the effects of fire on the concentration of nutrients in surface waters. Reston, Virginia: U.S. Geological Survey Open-File Report 2004-1296, pp. 1-23. 
Rathbun GB, Scott NJ Jr, Murphey TG. 2002. Terrestrial habitat use by Pacific pond turtles in a Mediterranean climate. Southwest Nat 47: 225-235.

Rees M, Roe JH, Georges A. 2009. Life in the suburbs: behavior and survival of a freshwater turtle in response to drought and urbanization. Biol Conserv 142: 3172-3181.

Roe JH, Rees M, Georges A. 2011. Suburbs: dangers or drought refugia for freshwater turtle populations? J Wildl Manag 75: $1544-1552$.

Rowe JW, Gradel JR, Bunce CF. 2013. Effects of weather conditions and drought on activity of spotted turtles (Clemmys guttata) in a southwestern Michigan wetland. Am Midl Nat 169: 97-110.

Schwarzkopf L, Brooks RJ. 1985. Application of operative environmental temperatures to analysis of basking behavior in Chrysemys picta. Herpetologica 41: 206-212.

Sidis I, Gasith A. 1985. Food habits of the Caspian terrapin (Mauremys caspica rivulata) in unpolluted and polluted habitats in Israel. J Herpetol 19: 108-115.

Smith HG, Sheridan GJ, Lane PNJ, Nyman P, Haydon S. 2011. Wildfire effects on water quality in forest catchments: a review with implications for water supply. J Hydrol 396: 170-192.

Snover ML, Adams MJ, Ashton DT, Bettaso JB, Welsh HH. 2015. Evidence of counter-gradient growth in western pond turtles (Actinemys marmorata) across thermal gradients. Freshw Biol 60: 1944-1963.

Spinks PQ, Thomson RC, Shaffer HB. 2014. The advantages of going large: genome-wide SNPs clarify the complex population history and systematics of the threatened western pond turtle. Mol Ecol 23: 2228-2241.

Spinks PQ, Thomson RC, McCartney-Melstad E, Shaffer HB. 2016. Phylogeny and temporal diversification of the New World pond turtles (Emydidae). Mol Phylogenet Evol 103: 85-97.

Staley DM, Smoczyk GM, Reeves RR. 2013. Emergency assessment of post-fire debris-flow hazards for the 2013 Powerhouse fire, southern California. Reston, Virginia: U.S. Geological Survey Open-File Report 2013-1248, 3 plates, 13 p., http://pubs.usgs.gov/ of $/ 2013 / 1248 /$

Steen DA, Hopkins BC, Van Dyke JU, Hopkins WA. 2014. Prevalence of ingested fish hooks in freshwater turtles from five rivers in the southeastern United States. PLOS ONE 9: e91368.
Stephens S, Meixner T, Poth M, Mcgurk B, Payne D. 2004. Prescribed fire, soils, and stream water chemistry in a watershed in the Lake Tahoe Basin, California. Int J Wildland Fire 13: 27-35.

Stubbs D, Swingland IR, Hailey A, Pulford E. 1985. The ecology of the Mediterranean tortoise Testudo hermanni in northern Greece (the effects of a catastrophe on population structure and density). Biol Conserv 31: 125-152.

Swartz CD, Donnelly KC, Islamzadeh A, et al. 2003. Chemical contaminants and their effects in fish and wildlife from the industrial zone of Sumgayit, Republic of Azerbaijan. Ecotoxicology 12: 509-521.

Thomson RC, Wright AN, Shaffer HB. 2016. California amphibian and reptile species of special concern. Berkeley: University of California Press, $408 \mathrm{p}$.

Verkaik I, Rieradevall M, Cooper SD, Melack JM, Dudley TL, Prat N. 2013a. Fire as a disturbance in mediterranean climate streams. Hydrobiologia 719: 353-382.

Verkaik I, Vila-Escalé M, Rieradevall M, Prat N. 2013b. Seasonal drought plays a stronger role than wildfire in shaping macroinvertebrate communities of Mediterranean streams. Int Rev Hydrobiol 98: 271-283.

Wantzen K, Rothhaupt KO, Mörtl M, Cantonati M, Tóth LG, Fischer P. 2008. Ecological effects of water-level fluctuations in lakes: an urgent issue. Hydrobiologia 613: 1-4.

Westerling AL, Hidalgo HG, Cayan DR, Swetnam TW. 2006. Warming and earlier spring increase western U.S. forest wildfire activity. Science 313: 940-943.

Wings O, Rabi M, Schneider JW, et al. 2012. An enormous Jurassic turtle bone bed from the Turpan Basin of Xinjiang, China. Naturwissenschaften 99: 925-935.

Woodhouse CA, Meko DM, Macdonald GM, Stahle DW, Cook ER. 2010. A 1,200-year perspective of 21st century drought in southwestern North America. Proc Natl Acad Sci USA 107: 21283-21288.

Zaragoza G, Rose JP, Purcell K, Todd BD. 2015. Terrestrial habitat use by western pond turtles (Actinemys marmorata) in the Sierra foothills. $J$ Herpetol 49: 437-441.

Zielinski WJ, Barthalmus GT. 1989. African clawed frog skin compounds: antipredatory effects on African and North American water snakes. Anim Behav 38: 1083-1086.

Cite this article as: Lovich JE, Quillman M, Zitt B, Schroeder A, Green DE, Yackulic C, Gibbons P, Goode E. 2017. The effects of drought and fire in the extirpation of an abundant semi-aquatic turtle from a lacustrine environment in the southwestern USA. Knowl. Manag. Aquat. Ecosyst., 418, 18. 